\title{
OPISTOJEN PERIMMÄISET KYSYMYKSET VAILLA RATKAISUA
}

\author{
Juha Sihvonen, 1993. Onko vapaat sivistystyöt tehty? Tutkimus kansalaisopistojen so- \\ peutumisesta yhteiskunnallisiin muutoksiin. Lisensiaattitutkimus, Tampereen yliopiston \\ kasvatustieteellinen laitos.
}

Juha Sihvosen, Valkeakosken työväenopiston rehtorin, lisensiaattitutkimus "Onko vapaat sivistystyöt tehty?" on erittäin tervetullut ja tarpeellinen kansalais/työväenopistokentälle. Se on riittävän konkreettinen ja selkeä luettavaksi. Sellaista käytännön työtä tekevät opistoihmiset juuri tarvitsevat. Tutkimus hakee vastauksia tutkijan esittämiin kysymyksiin, mutta hän esittää edelleen joukon lisäkysymyksiä, jotka puolestaan eivät jätä kylmäksi ainakaan alalle vannoutuneita rehtoreita.

Tutkimus on valmistunut kesän 1993 kuluessa; tutkimusmateriaali on kerätty 1992 aikana. Nyt eletään kesää 1995 ja niinpä on mielenkiintoista analysoida tutkimusta tämän päivän näkökulmasta.

Tutkimuksen perustana on 26 rehtorille lähetetty kyselylomake. Vastaajat ovat mielestäni riittävän edustava "otos" opistojen rehtorikunnasta. Rohkenisin sanoa, että kyselyyn osallistumattomat voisivat ottaa vastaan haasteen aloittaa keskustelu opistojen tilasta tässä ja nyt. Mutta onko meillä keskustelutaitoa ja sopivaa foorumia?

\section{Mistä tulemme ?}

Suomalaisten kansalais/työväenopistojen taival on varsin pitkä verrattuna esimerkiksi maamme kansanopetuksen tai kansakoululaitoksen historiaan. Siksi on paikallaan, että Juha Sihvonen analysoi ja luokittelee opistojen eri kausia, jotka on toki vain nähtävissä jälkikäteen. Kun itsekin olen ollut vaatimassa monessa yhteydessä aikuiskoulutukselle ja vapaalle sivistystyölle yhteiskunnallista oikeutusta maassamme mm. eduskunnalta, Sihvonen nostaa hienosti esille vapaan sivistystyön idean. Hän mukailee jäsentää ruotsalaisen tutkijan Gustavssonin vapaan sivistystyön ideaa vastakohtien avulla:

- "joko sivistyminen ymmärretään vapaaksi, päättymättömäksi prosessiksi tai sivistystä pidetään päämääränä ja kasvatuksen avulla saavutettuna lopputuloksena, - joko sivistys on kaikkien yhteiskunnan jäsenten oikeus tai sitä pidetään harvojen etuoikeutena - toisin sanoen vastakohta sivistyksellisen tasa-arvon ja elitismin välillä, - joko sivistyksellä pyritään ihmisen kokonaispersoonallisuuden kehittämiseen tai sivistyminen johtaa kapea-alaiseen erikoistumiseen.

Näillä kriteereillä jäsenneltynä vapaan sivistystyön idea määriteltiin Suomessa alkujaan siten, että sivistyminen on vapaa, päättymätön prosessi, johon kaikilla yhteiskunnan jäsenillä on oikeus osallistua, ja jonka tavoitteena on ihmisen kokonaispersoonallisuuden kehittäminen."

Voi vain kysyä tänä päivänä, kuinka paljon ideasta on jäljellä yhä enemmän markkinavetoistuvassa yhteiskunnassa ja kansalais/työväenopistossa? Edellä oleva vapaan sivistystyön idea pohdiskeluineen on eräs punainen lanka Sihvosen tutkimuksessa. Mielestäni pohdiskelussa on jopa kyse enemmästäkin kuin ns. vapaasta sivistystyöstä. Kyse on suomalaisen tai pohjoismaisen perussivistyksen tai -koulutuksen ydinkysymyksestä varsinkin nyt, kun arvioimme asemaamme Europan Unionin sisällä. Maastrichin sopimus 
antaa mahdollisuuden päättää kansallisesti koulutuksesta, mutta kuinka paljon haluamme olla loppujen lopuksi sopeutujia.

Sihvosen tutkimus ei sisällä mainintoja tai rinnastuksia Keski-Euroopan tilanteeseen. Meillä on vain sellainen iskostettu käsitys kentällä, että suomalainen kansalais/työväenopistolaitos on ainutkertainen ja tasokas aikuiskoulutusjärjestelmä maailmassa. Onko näin? Tuntuu siltä, että tässä on myös myyttisyyttä. Euroopan avautuessa "uudella ja vapaalla tavalla" EU:n myötä ja markkinatalouden saadessa kunnissa, valtion hallinnossa ja järjestöissä vahvemman otteen tuntuu kohta "historialliselta1ukea Sihvosen tutkimuksen analyysia opistotoiminnan perusarvoista ja tehtäväkäsityksestä. Näin nopeasti ajat muuttuvat!

Sihvosen tekemät analyysit ovat varmasti oikeita. ja kuten hän toteaa, eri tehtäväkäsitykset ja tehtäväalat eivät näy puhtaina pienessä mittakaavassa mutta suuressa kylläkin. Moni asia on toteutunut opistoissa eripituisella viiveellä. Taloudelliset vaikutukset eli laman seuraukset ovat näkyneet jo tutkimuksessa asennemuutoksena; tutkimusaineiston keruun jälkeen markkoina, vielä voimakkaampina asennemuutoksina ja henkilöstövähennyksenä. Vapaan sivistystyön henkilöstökasvu 1980-luvun lopulle on kääntynyt nimenomaan päätoimisen opetushenkilöstön nopeaksi supistumiseksi, joka parhaillaan jatkuu. Joko rehtorikunta on mukautunut markkinahenkisyyteen tai se on kuntatasolla kykenemätön puolustamaan laajimman vapaan sivistystyön laitoksen olemassaoloa ja pedagogista tasoa. Tutkimus ei ainakaan tuo esille sitä, että rehtorit olisivat hallinnollisessa ja taloudellisessa muutosprosessissa aktiivisesti konservatiivisia. Sen sijaan konservatiivisuutta on nähtävissä itse toiminta-ajatuksen muutoksessa.

Tutkimuksesta ei numerollisesti eikä sanallisesti tule riittävästi esille muiden aikuiskoulutusoppilaitosten toiminnan kasvu 1980-luvun alusta alkaen. Tosiasiassa ammatilliset aikuiskoulutuskeskukset ovat syöneet vapaan sivistystyön hyötymerkitystä valtakunnallisella ja kunnallisella tasolla. Ammatillisuus/työllisyys ovat nousseet jo ennen markkinahenkisyyttä suomalaista aikuiskoulutuspolitiikkaa ohjaaviksi tekijöiksi, kuten Juha Sihvonen toteaa aivan oikeasti. Ikään kuin tässä syklissä ei olisi tilaa humanistisuudelle!

Kun Juha Sihvonen kysyy: vieläkö vapaan sivistystyön perusideaa pidetään oikeana vai kuuluuko sekin niihin modernin yhteiskunnan myytteihin, jotka ovat aikansa eläneitä?", haluaisin todeta, että moni opisto on itse aktiivisesti vaikuttanut arvostuksensa puutteeseen. Kaikkien toiveiden toteuttaminen kasvun vuosina söi pois imagoa.

Kuten jo aiemmin totesin, Sihvonen nostaa konkreettisesti tutkimuksessaan esille kansalais/työväenopistojen historiallisen kehityksen 1990-luvun alkuun. Uusien ja vanhojen rehtoreiden kuin myös opettajien tulisi lukea nämä jaksot, jotta toiminnan identiteetti ja historiallinen perspektiivi kirkastuisivat; samalla selviäisi opistojen tilanne osana koulutusjärjestelmäämme.

\section{Usko muutokseen}

Tutkimuksessa ennakoitiin opistojen talouden heikkeneminen. Näin on tapahtunut varsinkin valtionosuuksissa (1992-95, noin 33 prosenttia), mutta myös kunnallisella tasolla. Kunnissa leikkaukset eivät ole kuitenkaan olleet yleensä yhtä rajuja kuin aluksi uskottiin. Opistot ovat pystyneet sittenkin perustelemaan tarpeellisuutensa kunnallisille päättäjille. Opetuksen "halpuus" on luultavasti ollut valttia ja suurehko valtionosuus.

Tutkimus osoitti, että opintomaksuja joudutaan nostamaan tulevina vuosina. Näin on käynytkin. Samalla on aktualisoitunut keskustelu, muuttuvatko opistot elitistisiksi. Rehtorit ovat osanneet tyydyttää opiskelijoiden tarpeita ja samalla kuitenkin karsia kannattamattomia kursseja pois. Taloudellinen lama on luonut oikeutuksen muutoksille, joita ei ehkä humanistisesta näkökulmasta katsottuna muutoin olisi tehty. Opistot ovat hakeneet olemassaololleen lisäaikaa osoittamalla markkinahenkisyyttä. 
Toisaalta työttömyyden raju nousu tutkimuksen valmistumisen aikoihin avasi uusia mahdollisuuksia opistojen toiminnalle. Opintosetelit työttömille, alennukset opintomaksuihin jne. ovat osoitus kansalaisten piilotajuisesta valmistautumisesta korkeaan työttömyyteen. Kansalaisten pitäminen eri tavoin henkisesti ja fyysisesti toimintakuntoisina on jo valtion ja kuntien virkamiesten mukaan kansallinen tehtävä, jota opistot omalta osaltaan tekevät. Näin opistot ovat "halpana" oppilaitoksena saamassa uudenlaisen yhteiskunnallisen tehtävän, jota ei ehkä perustellakaan enää vapaan sivistystyön idealla, vaan jollakin muulla, raadollisemmalla.

Tutkimuksessa ja sen taustamateriaalissa ennakoitiin opistojen yhdistämisiä ja lopettamisia melko nopeaksi prosessiksi. Todellisuudessa yhdistymisiä ja lopettamisia on ollut vain muutamia. Onkin oletettavaa, että kuntien verotulojen nopea kasvu säilyttää ikiomat eli nykyiset opistot. Toisaalta valtionosuudet ja yhdistelmärehtoreiden sallittavuus säilyttävät opistot, mutta miten käy opetuksen määrän ja laadun? Kuolevatko jotkut opistot pystyyn? Kuntien johtajat ja luottamushenkilöt ovat lainsäädännön (opistolaki ja kunnallislaki) muuttumisen jälkeen innostuneet uusorganisointiin, jollaista ei tutkimuksen tekohetkellä kukaan osannut ennakoida.

Tutkimustulokset ja sen jälkeinen muutosprosessi ovat käytännössä jokseenkin ristiriitaisat. Muutoksia on tapahtunut siellä, niissä ei odotettu ja päinvastoin. Usko muutoksen jatkuvuuteen elää voimakkaana, kuten tutkimuskin osoitti. Kriisi (saattaa olla liian voimakas ilmaisu oppilaitosmuodolle, joka eli jatkuvaa nousukautta 1980-luvun loppuun asti) opistojen osalta ei ole ohi. Päinvastoin opetussektorin muutokset ovat hitaita jopa niinkin kevyessä organisaatiossa, joka on opistoissa ja niiden ympärillä. Merkitseekö opistojen yhä laajemmin omaksuma palveluhenkisyys ja tyytyväiset asiakkaat sitä, että nopeisiin muutoksiin ei haluta mennä tietoisesti, vaikka siihen olisi tarvettakin? Tutkimus ei paljasta sitä, kuinka paljon opistot/rehtorit ovat "ajopuuteorian" toteuttajia.

\section{Ennustajan rooli}

Kuten aikaisemmin totesin, tutkimus on konkreettinen. Sen jaksaa lukea läpi ja vertailla sen tuloksia ja johtopäätöksiä nykypäivään.

Tutkijan ja tutkittavien ennusteet eivät aina toteudu tai ne toteutuvat toisessa muodossa tai nopeammin tai hitaammin. Sinällänsä voisi sanoa, että tutkija on odottanut nopeampia muutoksia kuin tutkittavat eli muut rehtorit. Todellisuudessa uskon, että tutkija on oikeassa, mutta hänen kiireensä on liian suuri. Tutkija näkee muutoksen tulevan opistoihin yhteiskunnan vaatimana. Rehtorit puolestaan tietävät kunnallisen hitauden ja henkilökohtaiset kytkökset kuntatasolla, mutta eivät kerro sitä. Siksi he (enemmistö) vastaavat, "ettei organisatorisessa asemassa tapahdu muutoksia". Yhtä väärässä oli opetushallituskin, kun se ennakoi 20-40 opiston lakkauttamista vuoteen 1995 mennessä yhdistymisten seurauksena.

Opistot ovat rehtorivetoisia kunnallisia "yrityksiä", joiden toiminta rakentuu sekoituksesta: paikallinen sivistystarve, opiskelijoiden pohjakoulutus ja koulutushalukkuus, rehtorin sivistykselliset intohimot ... kunnallinen/valtiollinen aikuiskoulutuspolitiikka... Tällaisessa tilanteessa ennustaminen saattaa jopa tuntua mahdottomalta. Opistot ovat kuntatasolla kansalaisten mielestä hyvin palvelevia organisaatioita, vaikka sen tehtäväkuvaa ei täysin tunnetakaan.

\section{Tutkimus jo tulokset}

Edellä olen tarkastellut Juha Sihvosen tutkimusta siten, mitä se on minussa herättänyt: kommentteja, uusia kysymyksiä, uusia selvityksen aiheita. Olen menetellyt mielestäni täysin pakinamaisesti. Juha Sihvonen on nostanut tutkimuksellaan esiin joukon tärkeitä kysymyksiä. Näitä ovat mm. vapaan sivistystyön idea, tappaako markkinahenkisyys vapaan sivistystyön, kuoleeko yhteistyöhalukkuus markkinavetoisuudessa, rehtoreiden muutoshalukkuus, rehtoreiden mukautuminen ympäristöönsä, hallinnon/lainsäädännön suuri 
ohjausmekanismi jne. Myös lukijalle nousee valtava määrä uusia kysymyksiä, jotka jäävät nyt vaille vastausta, mutta joihin seurantatutkimus tuo valaistusta. Seurantatutkimus tulisi tehdä samoille rehtoreille esimerkiksi viiden vuoden välein, jotta nähtäisiin heidän ja opistojen muuttuminen. Tutkimus olisi jonkinlainen kasvatushistoriallinen tai organisaatiohenkilökehityssosiologinen.

Juha Sihvosen tutkimus on erittäin arvokas opistojen johdolle, erityisesti rehtoreille. Ikäänkuin oman opiston tai oman rehtorikuvan löytyminen kiinnostanee lukijoita. Tämän lisäksi tutkimus sisältää valtavan määrän nykykielistä tietoa opistoliikkeen kehityksestä tähän päivään. Tutkija osoittaa hallitsevansa nimenomaan kansalais/työväenopistot sisältä ja ulkoa. Painetussa kirjassa toivoisi aiheisiin liittyvien kuvien ohella olla kuvia "hullutuksista", joihin lainsäädännön pikkutarkkuus ja eräiden hallintoherrojen omat tulkinnat aikanaan johtivat.

Tutkimus jättää edelleen auki monet opistojen perimmäiset kysymykset. Syy ei ole tutkijan, vaan asioiden vaikeuden ja kehityksen ennakoimattomuuden. Kansalais/työväenopistojen toiminnan tutkiminen on todella vaikeaa, koska kahta samanlaista ei löydä varmasti, toimintaympäristöstä ja opiskelijoista puhumattakaan. Juha Sihvosen valitsema tutkimustapa on ennakkoluuloton. Sitä kautta hän sai enemmän irti kuin perinteisillä tavoilla. Toivottavasti tutkimus herättää laajan keskustelun rehtoreiden ja koulutuspolitikkojen keskuudessa ja kesken. Juha Sihvonen ansaitsee opistoaktiivien puolesta suuret kiitokset erinomaisesta työstä. 